\title{
Genocide and the Question of Philosophy
}

\section{Elenita dIR. Garcia}

\begin{abstract}
This paper looks into the issues surrounding the concept of genocide and examines Philosophy's role in it by looking into contemporary scholars' assessments of its influences that led to the Jewish Holocaust and other genocides. It shows that although Philosophy, in its Western guise, may have contributed to these atrocities, its Eastern counterparts may have something to offer in terms of countering such tendencies. Whether within Eastern or Western traditions, this paper calls for Philosophy to examine itself and effectively address ethical and social issues in history and take on its role of properly shaping the way we think and act.
\end{abstract}

Keywords: genocides, holocaust, racism, western and non-western thought

\section{Philosophy, Genocides, and Other Atrocities ${ }^{1}$}

$\mathrm{U}$

NESCO's Director General from 1999 to 2009, Koichiro Matsuura, during the International Day of Commemoration in Memory of the Victims of the Holocaust on 27 January 2009, said that the Organization:

continues to contribute to raising awareness on all forms of discrimination, which includes the fight against antiSemitism, and all actions and words which might be interpreted as Holocaust denial. Holocaust education should recognize no boundaries in terms of curricular subject, location, and age and group of learners. It

${ }^{1}$ Adapted from Elenita dLR. Garcia, “What's the Matter with Philosophy? Reflections on Philosophy and its Role in Genocides," Professorial Chair lecture presented at the Dr. Emerita S. Quito Professorial Lecture in the History of Thought, De La Salle University.

(c) 2017 Elenita dIR. Garcia

http://www.kritike.org/journal/issue 20/garcia june2017.pdf

ISSN 1908-7330 
should inspire our young to challenge anti-Semitism, racism, and extremism rather than to remain silent. ${ }^{2}$

It was in line with this sentiment that UNESCO dedicated World Philosophy Day on November 21, 2008 as a celebration of the $60^{\text {th }}$ anniversary of the Declaration of Human Rights. The General-Director referred to it as "of eminent philosophical importance," as the 1948 declaration "evokes the universality of human beings and their rights. It also provides an opportunity to revisit today some key concepts that underpin our modernity: human dignity, freedom and universality." 3

Eight years afterwards, these words are still worth reflecting on: "What exactly has philosophy done to merit this expectation from an international organization such as UNESCO? Have the hallmarks of reason, critical thinking and thought-clarifying questions helped in the prevention of atrocities throughout the modern world? We would like to say that philosophy has always been at the foundations of all disciplines, dealing with fundamental issues of human life. Unfortunately, it seems like philosophy has actually been silent about the terrible realities that involve moral transgressions, like genocides.

In 2005, John K. Roth edited a compilation of articles that has been subtitled "a philosophical guide" to genocide. The book, Genocide and Human Rights, discusses many issues that surround the concept of genocide, generally outlining the temperament of Western Philosophy that might have justified actual genocides in history. Although this paper does not intend to claim that cruelty is directly caused by Western ways of thinking or that nonWestern thoughts are never responsible for atrocities, it aims to echo and explore those issues, specifically as it has been committed during the Jewish Holocaust. It therefore inquires into the role of Philosophy in the Holocaust and other known genocides. Further, it intends to show that while there are philosophical views that tend to help facilitate genocidal atrocities, others might be of help in preventing them, particularly basic Eastern views regarding the self, others and the world.

2 Kö̈chiro Matsuura, "Message from Mr. Koïchiro Matsuura, Director-General of UNESCO on the occasion of the International Day of Commemoration in Memory of the Victims of the Holocaust," in UNESCO (27 January 2009), <http://unesdoc.unesco.org/images/0017/001794/179409e.pdf $>, 15$ October 2016.

${ }^{3}$ Koïchiro Matsuura, "Message from Mr. Koichiro Matsuura, Director-General of UNESCO, on the occasion of World Philosophy Day," in UNESCO (20 November 2008), $<$ http://en.unesco.kz/message-from-mr-koichiro-matsuura-director-general-of-unesco-on-theoccasion-of-world-2008-11-18>, 15 October 2016.

(c) 2017 Elenita dIR. Garcia

http://www.kritike.org/journal/issue 20/garcia june2017.pdf

ISSN 1908-7330

(cc) BY-NC-ND 


\section{GENOCIDE AND PHILOSOPHY}

\section{Genocidal Acts: Natal Alienation, Terror, Shame}

In 1944, Raphael Lemkin, in his Axis Rule in Occupied Europe, coined the term "genocide," putting together the Greek "genos," meaning "race" and the Latin suffix "-cide" that refers to killing. He claimed that two things are accomplished in genocide: first, to destroy the nationhood of the oppressed; second, to replace it with that of the oppressors'. This way, Lemkin showed that genocide does not necessarily involve murder, although mass murders are definitely genocidal. The Nazi project of "Germanization" of Europe clearly counts as genocide even without the mass murder of the Jews. ${ }^{4}$ The 1948 UN Convention on the Prevention and Punishment of the Crime of Genocide defined it in Article II as:

any of a number of acts committed with the intent to destroy, in whole or in part, a national, ethnic, racial or religious group: killing members of the group; causing serious bodily or mental harm to members of the group; deliberately inflicting on the group conditions of life calculated to bring about its physical destruction in whole or in part; imposing measures intended to prevent births within the group, and forcibly transferring children of the group to another group. ${ }^{5}$

Claudia Card finds this definition controversial ${ }^{6}$ because of what it excludes, for instance, political groups. Card reports that the term "political groups" has been dropped from the initial draft because, while one is born into a nation or religion and has had no choice in his or her race, one is not born with an inherent political creed. But protesters have shown that one is also not necessarily born into one's ethnic, national or religious group. Others, on the other hand, contend that politically triggered killings (also referred to as "politicide") is an old concept and need not be included in the new term in question. ${ }^{7}$ More interesting are the other kinds of "murder" that

\footnotetext{
${ }^{4}$ Robert Bernasconi, “Why Do the Happy Inhabitants of Tahiti Bother to Exist at All?” in Genocide and Human Rights: A Philosophical Guide, ed., John K. Roth (New York: Palgrave Macmillan, 2005), 140.

${ }^{5}$ United Nations, "Convention on the Prevention and Punishment of the Crime of Genocide," in United Nations Human Rights - Office of the High Commissioner (9 December 1948), $<$ http://www.ohchr.org/EN/ProfessionalInterest/Pages/CrimeOfGenocide.aspx $>, 15$ October 2016.

${ }^{6}$ Claudia Card, "Genocide and Social Death," in Genocide and Human Rights, 243.

7 Raimond Gaita also points out that the Soviets bullied the UN into dropping "political groups" from the definition because they didn't want the mass murders of political

(c) 2017 Elenita dIR. Garcia

http://www.kritike.org/journal/issue 20/garcia june2017.pdf

ISSN 1908-7330
}

(c) ) BY-NC-ND 
pass for genocide, making the requirement of physical murder unnecessary, just as Lemkin pointed out.

Card further asks: of the wide range of bodily or mental harm imaginable, which ones qualify as genocide? How many people must be killed? Must an intention to eliminate an entire group be successful? Hitler aimed to eliminate all Jews. He did not succeed, yet the Jewish Holocaust of Nazi time is considered the paradigm of genocide. This is because it is a "harm inflicted on its victims' social vitality." She continues,

... When a group with its own cultural identity is destroyed, its survivors lose their cultural heritage and may even lose their intergenerational connections...they may become "socially dead" and their descendants "natally alienated," no longer able to pass along and build upon the traditions, cultural developments (including languages), and projects of earlier generations. ${ }^{8}$

Card claims that social death is comparable to physical death. She takes natal alienation to be central to genocide. ${ }^{9}$ The Holocaust is a genocide because although some Jews were not murdered, they nevertheless suffered loss of connection to their culture or faith. The fact that those who survived, either because they migrated to "safe" countries or they reestablished connections with relatives and members of the community after the Holocaust, ${ }^{10}$ - and thus were able to practice their culture again-does not mean that the Nazi crime was not genocidal. ${ }^{11}$

Raimond Gaita critiques the idea of natal alienation as the essence of genocide because this intention to destroy "... a people's culture and the imposition of the culture of the conqueror on them can be an expression of respect for them that goes hand in glove with an expression of contempt for

groups during Stalin's time to be called genocidal acts. Raimond Gaita, "Refocusing Genocide: A Philosophical Responsibility," in Genocide and Human Rights, 158-159.

${ }^{8}$ Ibid., 248.

${ }^{9}$ Ibid.

${ }^{10}$ For an account in literary fiction (that mirrors actual events in the authors' lives) of women who are not able to cope with normal life because of their experience in the concentration camps, see Inbar Raveh and Rotem Wagner, I Never Even Lived: A Teaching Unit - Women in Holocaust Literature (Jerusalem: Yad Vashem, 2000). Some committed suicide after a while. Card would consider this a failure to revive social identity and existence-a case of social death.

${ }^{11}$ Jewish philosopher Laurence Modekhai Thomas, according to Card, does not consider the Jews to be natally alienated because the Jewish society was able to continue after the Holocaust. Thomas reserves natal alienation to ethnic groups like the slaves who were born into situations that prevent them from having knowledge of and practicing their historico-cultural traditions. See Card, "Genocide and Social Death."

(c) 2017 Elenita dIR. Garcia

http://www.kritike.org/journal/issue 20/garcia june2017.pdf

ISSN 1908-7330 


\section{GENOCIDE AND PHILOSOPHY}

their culture."12 Gaita argues that if Nazism succeeded and became the essential culture of Europe, to bring the Europeans back to the way they were before Nazism was to impose on them-as a "moral and political imperative" -that would also constitute a course of action that would alienate them from their known culture. For Gaita, the Nazi intention to eliminate the Jews was done out of contempt for the Jews: "It was the cool, radical contempt for the very existence of the Jewish people that has made the Holocaust so chilling to many who have studied it." 13

Gaita points out that the Nazis' "Final Solution" was not a project intended for that end-of-war period. It was meant to continue as a post-war policy because it was considered a "civic ideal" to engage in it in times of peace. Similarly, Norman Geras shows that the Holocaust is "chilling" because the atrocities committed threaten the existence of all of humanity; it terrorizes all of us: "They terrorize not just those they put under immediate attack, or those closely threatened by or in the vicinity of such attack, but human beings in general." 14

On the other hand, Michael Morgan focuses on the sense of shame that the Holocaust triggered, not only in the prisoners in the camp but also in their liberators. He relates how the prisoners come to know shame through the various ways the Nazis would treat them in the camp. The poet Primo Levi writes about the way he and a couple of other inmates were sent to the laboratory for experiments, and how they immediately noticed their "filth," compared to the girls that worked there. Levi says,

Faced with the girls of the laboratory, we three feel ourselves sink into the ground from shame and embarrassment. We know what we look like .... We are ridiculous and repugnant. Our cranium is bald on Monday, and covered by a short brownish mould by Saturday. We have a swollen and yellow face ... our neck is long and knobbly ... Our clothes are incredibly dirty, stained by mud, grease, and blood ....15

Yet, when the Russian soldiers finally freed them, they also felt that shame. Seeing how the victims have been abused, starved and stripped of their identities, the liberators couldn't smile nor look at anything. They were

\footnotetext{
${ }^{12}$ Gaita, “Refocusing Genocide,” 158-159.

${ }^{13}$ Ibid., 161.

${ }^{14}$ Norman Geras, "Genocide and Crimes against Humanity," in Genocide and Human Rights, 174

${ }^{15}$ Michael Morgan, "Shame, the Holocaust, and the Dark Times," in Genocide and Human Rights, 313.

(c) 2017 Elenita dIR. Garcia

http://www.kritike.org/journal/issue 20/garcia june2017.pdf

ISSN 1908-7330
}

(c) BY-NC-ND 
silent with that same shame. ${ }^{16}$ Although Levi says that the soldiers' shame is the same as the inmates', it seems they are triggered by two different experiences, like two sides of the same coin. One is the shame in being reduced to a deplorable state of existence, and the other, shame in not being able to stop it or do anything about it.

Given the atrocities that are still going on all over the world, it is not surprising that the definition of "genocide" remains wanting and controversial. But as these scholars now address it, by their practice they also address the issue of Philosophy's role in it. If Philosophy shapes the way we think and the way we view the world, then we will have to accede that it has somehow been remiss in the performance of its role. As Roth shows, many great philosophers have helped advance human rights and fight for human equality. But sadly, many have also helped political regimes that later turned genocidal thrive. ${ }^{17}$ It is perhaps about time that Philosophy faced its "shadow," own up to this responsibility, and address these issues.

\section{Racist Tendencies in Western Thought}

Colin Tatz claims that racial theories that favored the Europeans or encouraged racism have existed all throughout history, and they are found in the works of great thinkers from Plato ${ }^{18}$ through Aquinas, ${ }^{19}$ and the thinkers

16 Ibid., 309

${ }^{17}$ John K. Roth, "Prologue: Philosophy and Genocide," in Genocide and Human Rights, xvii-xviii.

18 See Plato, The Republic, trans. by C.D.C Reeve (Indianapolis, Cambridge: Hackett Publishing Company, Inc., 2004). Hereafter cited as The Republic. Plato believes that there are different classes that make up the city. In a hierarchical order, he identified them as those who love wisdom (the philosopher-kings), those who love honor (the Warriors), and those who love money (the Artisans). Each one also has three soul-parts - the intellectual, the affective, and the appetitive (The Republic, 580d), but the intellect is stronger in those who love wisdom, while appetite is stronger in the lowest class. He also identified them as gold, silver, and bronze, respectively (ibid., 415a) and claimed that only those of gold are qualified to rule while those of the lower classes must be subjected to their rule in order to temper their appetites. Plato also envisioned that the state would monitor the sexual activity and reproduction of the citizens, communally caring for offsprings of good parentage and taking away those of inferior ones or those infants which are deformed-obviously a discourse on eugenics. (ibid., 560c) Plato also spoke of stereotypes, claiming Thracians and Scythians to be "spirited" and that Phoenicians and Egyptians love money, while the people of their "part of the world" truly love wisdom. (Ibid., 436a), thereby insinuating that they are the best people there is.

19 Aristotle, Politics, trans. Benjamin Jowett, in Internet Classic Archives $<$ http://classics.mit.edu/Aristotle/politics.mb.txt $>, 9$ March 2017. Hereafter cited as Politics. Like Aristotle who thought there were those who were by nature slaves because their souls were not fully formed and were fit only for physical labor, who claimed that "the use made of slaves and of tame animals is not very different" (Politics, Book I, Part V).

St. Thomas Aquinas says of slaves, "Men pre-eminent in understanding naturally take the command; while men poor in understanding, but of great bodily strength, seem by nature

(c) 2017 Elenita dIR. Garcia

http://www.kritike.org/journal/issue 20/garcia june2017.pdf

ISSN 1908-7330 


\section{GENOCIDE AND PHILOSOPHY}

of the Enlightenment period, especially Kant ${ }^{20}$ and Hegel, ${ }^{21}$ have all written on the superiority of their race. David Hume, observing the negroes of his time, saw them to be naturally inferior to the whites, saying that among them there have been no sciences or arts, and likened them to parrots, "who speak a few words plainly." 22 And for John Locke, it did not help their case that they were usually of the nomadic, hunter-gatherer tribes that did not understand the value of property and therefore, did not know what to do with land, a business solely for the civilized people. ${ }^{23}$ Even Voltaire explained racial

designate for servants, as Aristotle says in his Politics, [667] with whom Solomon is of one mind, saying: The fool shall serve the wise (Prov. xi, 29)" (Summa contra Gentiles, 3, 81; p. 449) and "under every government the freemen are provided for their own sakes, while of slaves this care is taken that they have being for the use of the free." (Summa contra Gentiles, 3, 1121 p. 489). Thomas Aquinas, Summa contra Gentiles, trans. by Joseph Rickaby, S.J., annotated and abridged version, in The Catholic Primer's Reference Series: Of God and His Creatures (The Catholic Primer, 2005).

${ }^{20}$ Kant agrees with Hume about the blacks and described them as "vain" and "have by nature no feeling that rises above the trifling." Immanuel Kant, Observations on the Feelings of the Beautiful and the Sublime, trans. by John T. Goldthwait (Berkeley, Los Angeles, CA: University of California Press, 2003), 313.

${ }^{21}$ See Georg Wilhelm Friedrich Hegel, The Philosophy of History, trans. by J. Sibree (Ontario: Batoche Books, 2001). Hereafter cited as Philosophy of History. In The Philosophy of History, Hegel says, "The German nations, under the influence of Christianity, were the first to attain the consciousness that man, as man, is free: that it is the freedom of Spirit which constitutes its essence" (Philosophy of History, 32). Furthermore, "The History of the World travels from East to West, for Europe is absolutely the end of History, Asia the beginning ... The East knew and to the present day knows only that One is Free; the Greek and Roman world, that some are free; the German World knows that All are free" (ibid., 121). Of the Africans, he says, "The Negro, as already observed, exhibits the natural man in his completely wild and untamed state. We must lay aside all thought of reverence and morality - all that we call feeling - if we would rightly comprehend him; there is nothing harmonious with humanity to be found in this type of character. The copious and circumstantial accounts of Missionaries completely confirm this, and Mahommedanism appears to be the only thing which in any way brings the Negroes within the range of culture" (ibid., 111).

${ }^{22}$ David Hume, "Of National Characters," in Essays, Moral, Political, and Literary, in Library Economics Liberty, <http://www.econlib.org/library/LFBooks/Hume/hmMPL21.html\#PartI $>$, 5 March 2017, footnote 10, as quoted in Colin Tatz, "The Doctorhood of Genocide," in Genocide and Human Rights, 85.

${ }^{23}$ The debate on Locke's racism ensued because of his well-known contribution to the idea of a liberal government and his apparent support of slavery. "Every freeman of Carolina shall have absolute power and authority over his negro slaves, of what opinion or religion soever." John Locke, The Fundamental Constitutions of Carolina: March 1, 1669, in The Avalon Project: Documents in Law, History, and Diplomacy, <http://avalon.law.yale.edu/17th cen-tury/nc05.asp>, 7 March 2017, Art. 110. His work on the idea of property is also interpreted by some scholars as having facilitated the removal of the Native Americans from their lands, for they are thought to not understand the idea of property. Known during his time as "savages," Native Americans were seen by Locke to be like children, idiots and illiterate people. See John Locke, An Essay Concerning Human Understanding, in Some Texts from Early Modern Philosophy (2012), <http://www.earlymoderntexts.com/assets/pdfs/locke1690book1.pdf $>, 7$ March 2017, Bk. I, Ch. II, Par. 27. See also Julie K. Ward, “The Roots of Modern Racism: Early Modern Philosophers on

(c) 2017 Elenita dIR. Garcia

http://www.kritike.org/journal/issue 20/garcia june2017.pdf

ISSN 1908-7330

(cc) BY-NC-ND 
differences by conjecturing that not everyone was a descendant of Adam and Eve. ${ }^{24}$ Tatz shows that although most of these claims started as mere opinions derived from observations, the development in science and technology allowed them to be backed up by scientific proofs, which later warranted the removal of the undesirable elements of society in the name of selfpreservation. ${ }^{25}$

On the other hand, David Patterson sees this as the increased tendency to see the ego as central, allowing for "the philosophical erasure of God," 26 by the loss of the "human-to-divine" relationship that goes hand in hand with "human-to-human" ones. Without the former, the aura of sacrality is removed from the human, making killing quite easy to do. ${ }^{27}$ If the human being is no longer sacred, then there is no thinking twice about exterminating $i t$, as there is no longer any offense in doing so. The ego then becomes the center and all meanings derive from it. Its freedom and autonomy allows it, as the Kantian Categorical Imperative ${ }^{28}$ commands it, to turn personal maxims into universal laws. Michael Mack reaches a similar conclusion showing that evil has actually been legitimized by the philosophy of History, specifically that of the Hegelian type, which glorified the Cunning of Reason at the expense of individual happiness. In Hegel, what matters is the Whole: All will be revealed at the end of the rational project. "The refinement of reason goes hand in hand with the development of the mindset that made

Race," in The Critique, (September/October 2016), <http://www.thecritique.com/articles/theroots-of-modern-racism/>, 7 March 2017.

${ }^{24}$ Tatz, "The Doctorhood of Genocide," 84-85. Voltaire asks in Septieme Lettre d'Amabed, "C'est une grande questionparmi eux s'ils sont descendus des singes, ou si les singes sont venus d'eux. Nos sages ont dit que l'homme est l'image de Dieu." ("It is a big question whether the Africans are descended from monkeys or whether the monkeys come from them. Our wise men have said that man was created in the image of God."). Voltaire, "Septième Lettre d'Amabed," in Les Lettres d'Amabed, vol. 21 of Oeuvres Complete de Voltaire (Paris: Garnier, 1877), 462. [Voltaire, "Seventh Letter of Amabed," in The Letters of Amabed, vol. 21 of Complete Works of Voltaire (Paris: Garnier, 1877), 462.]

${ }^{25}$ Tatz, "The Doctorhood of Genocide," 84-85.

${ }^{26)}$. Recall Nietzsche's "God is Dead" pronouncement. See Friedrich Nietzsche, The Gay Science, trans. by Walter Kaufmann (New York: Random House, 1974), 167, 279.

${ }^{27}$ David Patterson, “The Philosophical Warrant for Genocide," in Genocide and Human Rights, 95.

${ }^{28}$ Although Kant spoke of cosmopolitanism, a universal community where a violation of rights in one part could be felt everywhere, he also spoke of the difference between civilized and barbaric peoples and believed that only the Europeans have the capacity and the talent to move on in history. He was doubtful about the non-Europeans, especially the blacks and the Native Americans and thought they would be wiped out eventually because they would not be able to face up to the challenges that came their way. See Bernasconi, "Why do the Happy Inhabitants of Tahiti Exist at All?"

(c) 2017 Elenita dIR. Garcia

http://www.kritike.org/journal/issue 20/garcia june2017.pdf

ISSN 1908-7330

(cc) BY-NC-ND 


\section{GENOCIDE AND PHILOSOPHY}

Auschwitz possible." ${ }^{29}$ This observation is aptly echoed by Bernasconi who writes,

... neither Immanuel Kant nor G.W.F. Hegel advocated mass killing, but those magisterial figures in the tradition of Western thought unwittingly contributed to the formation of a culture of genocide...by proposing philosophies of history that were designed to give meaning to humanity as a species, while nevertheless embracing an idea of progress from which some races were excluded because they allegedly lacked the talents that would enable them to be full participants in humanity's future. Their findings "answered" the question of why the "white race" existed, but did little to explain the existence of the races whose historical agency had been denied. ${ }^{30}$

Similarly, Leonard Grob identifies the problem of philosophy as an obsession with ontology at the expense of ethics-the issue that the philosopher Emmanuel Levinas has been critiquing in his works. In this "province of being," Grob says, the "I" is sovereign and directs everything according to its own meaning-giving power. It has the power to totalize from this point of view, which makes it intolerant of difference. This egoist tendency is what contributes to genocidal thinking. For instance, the Nazis saw the Jews in racial terms and saw them as a whole, not as individuals. Next, they did not give them a human status. Who was to say they were not correct in this assessment? If the " $\mathrm{I}$ " is the source of all meaning, and that meaning is the only legitimate one, then one acts on it because one has the power and autonomy to do so. For Levinas, this is the reason that Philosophy especially after the Enlightenment period that espoused this thinking, might have been "a fertile ground in which genocide [could] grow and even thrive." The only way to combat this is for Philosophy to start examining itself. ${ }^{31}$

Western Philosophy, according to Paul Santilli, is also unable to concern itself with the body, especially the suffering body. ${ }^{32}$ Philosophy has always identified itself with the mind that can attain objectivity and

\footnotetext{
${ }^{29}$ Michael Mark, "The Rational Constitution of Evil: Reflections on Franz Baermann Steriner's Critique of Philosophy," in Genocide and Human Rights, 105-106.

${ }^{30}$ Bernasconi, "Why do the Happy Inhabitants of Tahiti Exist at All?" 139.

${ }^{31}$ Leonard Grob, "Genocide and the Totalizing Philosopher: A Levinasian Analysis," in Genocide and Human Rights, 133.

32 Paul Santilli, "Philosophy's Obligation to the Human Being in the Aftermath of Genocide," in Geocide and Human Rights, 223.

(c) 2017 Elenita dIR. Garcia

http://www.kritike.org/journal/issue 20/garcia june2017.pdf

ISSN 1908-7330
}

(c) BY-NC-ND 
universality. The Cartesian split between mind and body, as old as the Platonic forms and shadows, has always been taken for granted, and importance has always been on the side of the intangible. As such, Philosophy has been ill-equipped to deal with issues regarding the body, unless in a scientific, non-existential way. Santilli is quick to note that the proper orientation to suffering is not pity, as pity is, as Hannah Arendt put it, "a selfindulgent arousal of the heart that feeds on the misfortunes of others." The attitude must be that of solidarity - a recognition that not you alone suffer, but all of us, as we all belong together. ${ }^{33}$ As Levinas writes of this empathy, it "describes the suffering and vulnerability of the sensible as the other in me. The other is in me and in the midst of my very identification." 34

Philosophy and philosophers do seem to have quite a lot to answer for. Thomas Simon, citing the Serbian case $^{35}$ as an instance of how professional philosophers helped people harbor racist sentiments, laments this fact,

Sadly, rather than having situations where philosophers help us to understand injustices, we may have far more cases where professional philosophers stand accused of aiding and abetting atrocities. These circumstances suggest that philosophers need to think about their own discipline in relation to the problem of evil and, in particular, about the relationships between philosophy and genocide. ${ }^{36}$

Although not all philosophers have kept silent regarding these issues, those who wrote and spoke about them may have been few. Philosophy, as Roth realizes, has an important role in encouraging everyone to raise their voices in order to prevent genocide. Having prided itself with critical methods, philosophy must be able to deconstruct racial thinking and

${ }^{33}$ Ibid., 225.

${ }^{34}$ Emmanuel Levinas, Otherwise than Being, or, Beyond Essence, trans. A. Lingis (The Hague: Nijhoff, 1981), 125. See also, Simon Lumsden, "Absolute Difference and Social Ontology: Levinas Face to Face with Buber and Fichte," in Human Studies, 23 (2000): 227-241. Here, Lumsden discusses Levinas' "face to face" as contrasted against the Fichtean transcendental ego and Buber's I-Thou relationship. He shows that Levinas sees Heidegger's empathy (Einfuhlung) as still a self-relation devoid of true alterity but nevertheless argues for an empathetic relation to the Other as his sense of responsibility is affective rather than cognitive.

35 The philosopher Mihailo Markovic helped push the Greater Serbia ideology and helped Slobodan Milosevic form an extreme form of nationalism. The works of Markovic is intricately woven into the Belgrade regime which has been accused of genocide and crimes against humanity.

${ }^{36}$ Thomas W. Simon, "Genocide, Evil, and Injustice: Competing Hells," in Genocide and Human Rights, 66.

(c) 2017 Elenita dIR. Garcia

http://www.kritike.org/journal/issue 20/garcia june2017.pdf

ISSN 1908-7330 
have everyone think and act consistently with Philosophy's role in advancing human rights. Roth acknowledges that Philosophy is not the only discipline that can do this, but it is "the vanguard of those who value and practice thinking that questions assumptions, asks for evidence, and tracks the connections and implications of ideas." 37 We can therefore no longer ignore this task. Our history and the threat of genocide, as Frederick Sontag shows, should bring to mind and motivate philosophers "to help others to feel the importance of the Socratic injunction, 'Know thyself.'" 38

\section{The Self in Non-Western Traditions}

Could Philosophy have come to forget its original pursuit of wisdom? So many schools of thought have sprouted that we've lost the simplicity of the etymology of the term we use for the discipline, "love of wisdom." Is it possible the Philosophy -Western, that is - has lost its way, disdaining alternative wisdoms all this time, only to end up defeating itself?

Western Philosophy has always been wary of non-Western, wisdomseeking traditions. The latter's very close affinity with religion and the mythical, its focus on the community and the environment, its ultra-practical or ultra-spiritual preoccupations, and its seeming lack of concern for individual freedom, make it suspect in the realm of traditional Philosophy, with its strict demands for logic and objectivity. Yet, as we have shown, the concerns of Western Philosophy for the latter may have contributed to the phenomenon of genocide, especially its paradigmatic instantiation in the Holocaust. The next section briefly looks to the major traditions in the East Indian and Chinese-to see what insights they can offer to counter these effects.

\section{Hindu Karma}

Hinduism believes that there is an immutable law of the Universe that corrects everything through the workings of karma, the law of retribution. Every action engenders its own karmic return. It is therefore imperative that one becomes aware of this in order to avoid negative karmic results. While "... the Law of Karma binds the doer to the fruits of his deeds ...," nonattached living frees one from it. ${ }^{39}$ Ultimately, however, proper

${ }^{37}$ John K. Roth, “Genocide and the 'Logic' of Racism," in Genocide and Human Rights, Human Rights, 31.

38 Frederick Sontag, "How Should Genocide Affect Philosophy?" in Genocide and

${ }^{39}$ See S.K. Saksena, "Relation of Philosophical Theories to the Practical Affairs of Men," in The Indian Mind, ed. by Charles A. Moore (Honolulu: East-West Center Press, 1967).

(c) 2017 Elenita dIR. Garcia

http://www.kritike.org/journal/issue 20/garcia june2017.pdf

ISSN 1908-7330

(cc) BY-NC-ND 
understanding of the karmic cycle should make one avoid karmic returns altogether, positive or negative through the practice of non-attachment. Karma is closely connected to the cycle of life or samsara. One is reborn over and over again until all karmic produce have been reaped. Then and only then can one achieve spiritual liberation or moksa. ${ }^{40}$

Moksa is the realization that one's self, atman, is not separate from the basic substrate of the whole universe, called Brahman. Hinduism's major texts, the Upanishads, all point to the eventual realization that Brahman is identifiable with atman and that ignorance of this is the cause of return to this world in the cycle of rebirth. But multiplicity and difference are illusory. Thus, as the Bhagavad-Gita says, to the enlightened one, the gentle brahmana (spiritual person), the cow, the elephant, the dog and the dog-eater (outcaste) are seen with equal vision. ${ }^{41}$ Similarly, the story of Uddalaka and Svetaketu from the Brihadaranyaka Upanishad points to the oneness of everything in the world,

My child, the rivers that run in the different directions rise from the sea and go back to the sea. Yet the sea remains the same. The rivers, while in the sea, cannot identify themselves as one particular river or another. So also creatures that have come from Sat know not that they have come from that Sat, although they become one or the other again and again. ${ }^{42}$

\section{Buddhist Karuna}

Opposed to the basic view of Hinduism, Buddhism denies the existence of the atman, the self that endures and remains the same lifetime after lifetime of being reborn. Instead, it teaches non-self, or the lack of any permanent substance that exists outside of "causes and conditions." But it retains the belief in karma and still believes that actions reap consequences. Thus, Buddhism preaches compassion or karuna not just for fellow human beings but for all sentient beings. It is the supreme dharma, or path of

${ }^{40} \mathrm{Karma}$ is not punitive, as it is often perceived. Its intricate link with the cycle of rebirth allows atman to work out its energies. It is therefore a process of spiritual liberation, and not oppression. See P.T. Raju, "Religion and Spiritual Values in Indian Thought," in The Indian Mind, 195.

${ }^{41}$ Bhagavad Gita, in The Bhagavad Gita: With Commentaries of Ramanuja, Madhva, Shankara, and Others, <http://www.bhagavad-gita.us/?s=5.18>, 18 October 2016, 5.18.

42 "Uddalaka and Svetaketu - story from the Brihadaranyaka Upanishad," in Hindu Swayamsevak Sangh's Balagokulam: Hindu Dharma for Kid, Teachers, \& Parents, <http://www.balagokulam.org/kids/stories/uddalaka.php>, 18 October 2016.

(c) 2017 Elenita dIR. Garcia

http://www.kritike.org/journal/issue 20/garcia june2017.pdf

ISSN 1908-7330

(cc)) BY-NC-ND 


\section{GENOCIDE AND PHILOSOPHY}

righteousness. In the Metta Sutta (or Maitri Sutra), the text gives an example of how loving-kindness is practiced and how it frees one from rebirth.

Let no one deceive another or despise anyone anywhere, or through anger or irritation wish for another to suffer. As a mother would risk her life to protect her child, her only child, even so should one cultivate a limitless heart with regard to all beings. With good will for the entire cosmos, cultivate a limitless heart: Above, below, and all around, unobstructed, without enmity or hate. ${ }^{43}$

Basic in Buddhist thought is the practice of thinking good thoughts, speaking kindly and doing deeds of compassion. In mindful practice of these, one cultivates loving-kindness or active compassion, and at the same time, avoids gaining karmic energies that will perpetuate the cycle of rebirth, thereby avoiding harm to other beings that go with these negative energies. ${ }^{44}$

\section{Confucian Ren}

The Chinese preoccupation with social harmony is evident in the Confucian virtue of ren, usually translated as benevolence or righteousness. Based on the component parts of the character that represents it, however, it more appropriately means "consciousness-of-human-other." 45 For Confucianism, this is the ultimate essence which is manifest in various virtuous acts. Together with one's knowledge of his or her social status and role, and the corresponding propriety that such a role demands, ren makes an individual a cultured one-one who can avoid all faults out of his or her respect for others. He or she is called a junzi or a superior one. For this reason, Confucius emphasized, together with the Golden Rule, the "rectification of names" He says,

If names are not right then speech does not accord with things; if speech is not in accord with things, then affairs cannot be successful; when affairs are not successful, $l i$ and music do not flourish; when $l i$ and music do not

${ }^{43}$ Thanissaro Bhikkhu, trans., "18 Translations of the Metta Sutta - Sutta Nipata I.8," in Leigh Brasington's Website, <http://www.leighb.com/mettasuttas.htm>, 18 October 2016.

${ }^{44}$ Narayan Hemandas Samtani, trans., Gathering the Meanings: The Compendium of Categories: The Arthavinishcaya Sutra and Its Commentary Nibhandana (California: Dharma Publishing, 2002), Sutra VI, 107-114. The eight-fold path involves right understanding, right thoughts, right speech, right action, right livelihood, right effort, right mindfulness and right concentration, summarized as thinking, speaking, and acting in a good way.

${ }^{45}$ Alfredo Co, Philosophy of Ancient China (Manila: UST Printing Office, 1992), 107.

(C) 2017 Elenita dIR. Garcia

http://www.kritike.org/journal/issue 20/garcia june2017.pdf

ISSN 1908-7330

$((c))$ BY-NC-ND 
flourish, then sanctions and punishments miss their mark; when sanctions and punishments miss their mark, the people have no place to set their hands and feet.

Therefore, when a junzi gives things names, they may be properly spoken of, and what is said may be properly enacted. With regard to speech, the junzi permits no carelessness. ${ }^{46}$

Knowing one's proper name, one is able to learn how to act, since one's actions are to be congruent with one's words and thoughts. This congruence between thought, speech, and action is a strict requirement for the cultured individual. Confucius believes that although it is difficult to achieve, one must strive for its attainment because this is the only way to ensure that one will not do wrong. Confucius relates his own gradual development by saying that although he set his heart on learning the Decree of Heaven, it did not become second nature to him until he was 70: "At seventy, I follow the desires of my heart and do not overstep the bounds." 47

\section{Taoist Wei-wu-wei}

Taoism's emphasis on the Tao as the Way (of Nature) shows that everything is sacred. The Tao works for the general good. It is therefore imperative that one loses his or her mistaken idea of the self as separate from everything else. One is always in a web of connections with others within a community, and within the world in general. Thus, great emphasis is placed on non-harmful thinking, speaking and doing, while letting go of attachments. Although Taoism does not really prescribe what one ought to do in order to achieve this, it does describe what happens when it is not achieved. Thus, the Tao Te Ching, considered to be the manual of Taoist thought, says.

The Tao is infinite, eternal. Why is it eternal? It was never born; thus it can never die. Why is it infinite? It has no desires for itself; thus it is present for all beings. The Master stays behind; that is why she is ahead. She is detached from all things; that is why she is one with

\footnotetext{
${ }^{46}$ Confucius, The Analects of Confucius (An Online Teaching Translation), trans. by Robert Eno, in Indiana University Bloomington (2015), <http://www.indiana.edu/ p374/Analects_of_Confucius \%28Eno-2015\%29.pdf $>$, 18 October 2016, 13:3, pp. 68-69.

${ }^{47}$ Ibid., 2:4, p. 5.
}

(C) 2017 Elenita dIR. Garcia

http://www.kritike.org/journal/issue 20/garcia june2017.pdf

ISSN 1908-7330 


\section{GENOCIDE AND PHILOSOPHY}

them. Because she has let go of herself, she is perfectly fulfilled. 48

The Way goes by reversal. When one tries to do too much, the opposite is achieved. Thus, Taoism teaches wei-wu-wei. Literally, it means doing-without-doing, and has been taken to mean no-doing or non-action, as opposed to inaction. This does not mean inactivity or laziness. Rather, it means doing one's task, no more, no less, and then, letting go. If one overdoes his or her work, the result is usually undesirable. Thus, Chapter 9 says, "Fill your bowl to the brim and it will spill. Keep sharpening your knife and it will blunt. Chase after money and security and your heart will never unclench. Care about people's approval and you will be their prisoner..." 49 One must know when to stop and let go.

Without attachment, one is able to let go of the desire to control. When one doesn't control, one is most free and most powerful. This allows him or her to know the limits, and therefore, the parameters in which to work. Practicing this, one is not likely to ever run against any boundaries. Chapter 73 aptly says that "the Tao is always at ease. It overcomes without competing, answers without speaking a word, arrives without being summoned, [and] accomplishes without a plan ..." 50

Finally, the Tao goes by subtraction rather than addition. In various aspects of daily life, it knows that the more one has, in terms of thoughts and possessions, the less peace of mind he or she has. So the Taoist unlearns all the unnecessary things and keeps on embracing the Tao, because as she does this, she embraces all things.

Rushing into action, you fail. Trying to grasp things, you lose them. Forcing a project to completion, you ruin what was almost ripe. Therefore the Master takes action by letting things take their course. He remains as calm at the end as at the beginning. He has nothing, thus has nothing to lose. What he desires is non-desire; what he learns is to unlearn. He simply reminds people of who they have always been. He cares about nothing but the Tao. Thus he can care for all things. ${ }^{51}$

\section{The Individual is Social}

${ }^{48} \mathrm{Lao} \mathrm{Zi}$, Tao Te Ching, trans. by S. Mitchell, in Internet East Asian History Sourcebook (20 July 1995), < http://acc6.its.brooklyn.cuny.edu/ phalsall/texts/taote-v3.html\#7>, 18 October 2016, Ch. 7.

\footnotetext{
${ }^{49}$ Ibid., Ch. 9.

${ }^{50}$ Ibid., Ch. 73.

${ }^{51} \mathrm{Ibid} .$, Ch. 64.
}

(C) 2017 Elenita dIR. Garcia

http://www.kritike.org/journal/issue 20/garcia june2017.pdf

ISSN 1908-7330

(cc) BY-NC-ND 
What we have roughly sketched in the preceding section are only the highlights of some major traditions in the East. What we want to portray is that whatever the foundation of their thoughts is - typically spiritual in India, while practical in China - they all emphasize one thing: the individual is at the same time, social. The individual does not find itself isolated but it defines itself in a nexus of relationships within the world. As such, Eastern thought might offer an alternative framework in which genocidal tendencies might immediately be nipped in the bud, if they come up at all. What we've pointed out as the Western preoccupation with ontology and its penchant for giving the "I" a privileged status in determining meaning in the world might be countered with the Eastern attitude that the individual is transpersonal. As such, freedom is truly freedom only if it is afforded to everyone. After all, the self is - transpersonally-everyone.

In characterizing the Chinese mind, for instance, Charles Moore $(1967,5-7)$ emphasized its extremely humanistic bent. True to the Confucian tradition, he identified the primary philosophical concern of the Chinese as the cultivation of "sageliness within and kingliness without," showing at the same time, the inseparability of philosophy and life. Chinese philosophy then, Moore says, can actually be summarized as the learning of "the art of social living." Ethical consciousness is predominant, upholding respect for each individual and abiding by the concept of "original equality and original goodness" of each one. ${ }^{52}$ Moore $(1967,7-8)$ sums it up,

... the Chinese thought-and-culture tradition may be characterized by humanism, by its emphases upon the ethical, the intellectual (primarily with relation to life and activity), the aesthetic, and the social...without any aversion to material welfare and the normal enjoyments of life-and with an inner tranquility of spirit that pervades life in both prosperity and adversity, a tranquility born of a sense of harmony with Nature and one's fellow men. ${ }^{53}$

Similarly, Sarvepalli Radhakrishnan describes as part of the general characteristics of Indian philosophy, from the Orthodox schools to the many schools of the non-Orthodox systems, its belief in the intimate relationship of philosophy and life. In spite of its basic spiritual concern for final liberation,

\footnotetext{
${ }^{52}$ Charles A. Moore, "Introduction: The Humanistic Chinese Mind," in The Chinese Mind: Essentials of Chinese Philosophy and Culture, ed. by Charles A. Moore (Honolulu: East-West Center Press, 1967), 5-7.

${ }^{53}$ Ibid., 7-8.
}

(c) 2017 Elenita dIR. Garcia http://www.kritike.org/journal/issue 20/garcia june2017.pdf ISSN 1908-7330 


\section{GENOCIDE AND PHILOSOPHY}

it is very much concerned with how to live life in peace ${ }^{54}$ Its belief in the four stages of life (asramas), the four supreme ends (purusarthas), and the social organization (varna) make it very similar to the Chinese concern for living harmoniously with others by being mindful of social boundaries and duties (dharma).

In another work, however, Radhakrishnan comments on the changes in human history in the last century, focusing on the not-so-pleasant effects of science, having allowed people to

... solemnize their desires and organize their hatreds by propounding the theory of the predestination of races. This pernicious doctrine of fundamental racial differences and national missions is preventing the development of a true human community in spite of the closer linking up of interests and the growing uniformity of customs and forms of life ... ${ }^{55}$

Like the writers we have mentioned earlier, Radhakrishnan sees the Hegelian theory that what is is right and its accompanying implications as "a denial of moral authority," and a confusion of what is good with the real and "reduces the distinction between right and wrong to one of strong and weak." ${ }^{56} \mathrm{He}$ laments the loss of the ancient rules of war in India where only the ksatriyas or the warrior class go to war and the non-combatants (the other castes) are left alone to continue with their tasks. Thus, although some people are killed, no tribe gets wiped out, because there were always those who tilled the land and kept with their daily tasks. He continues,

... In modern wars whole populations are involved and there are no non-combatants. The forces must act with efficiency and indiscrimination. They may kill and maim, starve and ruin millions of human beings who are absolutely innocent. ${ }^{57}$

Radhakrishnan felt deeply about these issues and acted on them. As

\footnotetext{
54 Sarvepalli Radhakrishnan and Charles A. Moore, General Introduction to $A$ Sourcebook in Indian Philosophy, ed. by Sarvepalli Radhakrishnan and Charles A. Moore (Princeton, NJ: Princeton University Press, 1957), xxii-xxviii.

${ }_{55}$ Sarvepalli Radhakrishnan, Eastern Religions and Western Thought (New York: Oxford University Press, 1959), 350.

${ }^{56}$ Ibid., 360.

${ }^{57}$ Ibid., 363.

(c) 2017 Elenita dIR. Garcia

http://www.kritike.org/journal/issue 20/garcia june2017.pdf

ISSN 1908-7330

(c) BY-NC-ND
} 
a member of the Committee of Intellectual Cooperation of the League of Nations from 1931-1936, and as an Indian delegate to and later on chair of UNESCO's executive board in 1948, he wrote and researched on Hinduism and Christianity, and philosophy in general in order to promote peace.

\section{Philosophy after Genocide: Conclusion}

We do not mean to say that there are no problematic issues in Eastern thought that have influenced social issues. Nor are we saying that nonWesterners are incapable of genocidal thinking. We merely want to call attention to the gems of wisdom in the East that we've been ignoring simply because Eastern philosophy does not subscribe to the general tenets and methodologies of Western thought. When thinking well is supposed to lead to acting well, it seems that the worldview that does not allow too many dichotomies between thought and action, body and soul, heart and mind, is a better guideline than the one that does. Sometimes, what we need to confront is not the issue of "what conditions apply" to make something true or real, but whether something has been right or wrong. In this case, the typical Eastern openness to the use of intuition on top of reason, may be a better option when the concern is not ontology or epistemology but ethics. In Eastern traditions, all branches of Philosophy have one ultimate goal: to help us discern what is right and wrong and be able to live harmoniously with others, who are, after all, part and parcel of our self.

Earlier, we've mentioned Patterson's observation that genocide happens because of the philosophical erasure of God, which led to the loss of the holy in the human being. The many schools of thought in the East espouse different views of the divine and some of them are outright atheistic in stance. However, in the East, there is a pervading intuition that everything, not just human beings, is sacred. The whole universe is suffused with this subtle essence, whether Tao or Brahman, and each being shares in that spark of the divine within them. If we in the contemporary era, could somehow have this view in the background of thought, then perhaps, we'd think a thousand times before we launch a project bent on harming fellow human beings as well as the environment.

This paper is only a preliminary outlining of the issues that involve Philosophy with genocide. It is only meant to say that such a study is necessary. As Roger Gottlieb says, "it is barbaric to write philosophy as if the Holocaust had never happened." 58 If Philosophy were to continue this way, to justify racial theories and collude with science, to use argumentation only to

${ }^{58}$ Roger Gottlieb, “The Human Material is Too Weak," in Genocide and Human Rights, 291.

(C) 2017 Elenita dIR. Garcia http://www.kritike.org/journal/issue 20/garcia june2017.pdf ISSN 1908-7330 


\section{GENOCIDE AND PHILOSOPHY}

prove the logic of one's claim without concern for what is right or wrong, then Philosophy would be utterly irrelevant and Richard Rorty would be wrong in saying that "the goal of public philosophy is to find ways for us to be less cruel to each other." 59 Gottlieb continues,

... If we are not to repeat these patterns in our own time, we cannot turn aside the kinds of questions I have been raising here by saying, "This isn't my area. I'm more interested in the relation between epistemology and philosophy of mind. 60

Philosophy has to strive to be relevant again. Whether taking lessons from Western thought or getting inspiration from Eastern wisdom, it must take its skills and virtues toward the betterment of this world through the basic Socratic dictum, "Know thyself." If Philosophy were to change for the better, philosophers must examine themselves and find out which path they have taken so far and if that path has led them away from the original goal of the discipline. It must confront these issues, it must care for these issues and use the skill in argumentation to clarify concepts and turn them into practical and positive laws.

As Patterson's insights show us, if "philosophy" is the "love of wisdom," we have to ask what it is that we love when we love wisdom. ${ }^{61}$ Isn't Sophia-Wisdom-something higher than we are? Is it not something that imbues all of us with the holy and the sacred, and therefore, what we must love when we love wisdom is the other who is as sacred as we are? Philosophy must rethink itself and find out if its present concerns are matters of consequence. And we who are teaching the discipline must teach it not apart from life but within life and its concerns. This is important because, as Roth reminds us, when Plato said that philosophy began with awe and wonder, he knew that,

Philosophy does not come first but comes to life in the aftermath of preceding experience. Once it comes to life, philosophy takes on life of its own, which can be life-

${ }^{59}$ Gottlieb interprets Richard Rorty's arguments where he discusses historicists writers who emphasize the private sphere on the one hand, and those who emphasize the public one. Rorty writes, "Authors such as Marx, Mill, Dewey, Habermas and Rawls ... are engaged in a shared social effort-an effort to make our institutions and practices more just and less cruel." Richard Rorty, Introduction to Contingency, Irony and Solidarity (New York: Cambridge University Press, 1989), xiv.

${ }^{60}$ Gottlieb, “The Human Material is Too Weak," 293.

${ }^{61}$ Patterson, "The Philosophical Warrant for Genocide," 101. 
giving or life-threatening or many other things in between. ${ }^{62}$

Philosophy Department, De La Salle University, Manila, Philippines

\section{References}

Aristotle, Politics, trans. Benjamin Jowett, in Internet Classic Archives $<$ http://classics.mit.edu/Aristotle/politics.mb.txt $>, 9$ March 2017.

Bernasconi, Robert, "Why Do the Happy Inhabitants of Tahiti Bother to Exist at All?" in Genocide and Human Rights: A Philosophical Guide, ed., John K. Roth (New York: Palgrave Macmillan, 2005).

Bhagavad Gita, in The Bhagavad Gita: With Commentaries of Ramanuja, Madhva, Shankara, and Others, <http://www.bhagavad-gita.us/?s=5.18>, 18 October 2016.

Bhikkhu, Thanissaro, trans., "18 Translations of the Metta Sutta - Sutta Nipata I.8," in Leigh Brasington's Website, <http://www.leighb.com/mettasuttas.htm>, 18 October 2016.

Card, Claudia, "Genocide and Social Death," in Genocide and Human Rights: A Philosophical Guide, ed., John K. Roth (New York: Palgrave Macmillan, 2005).

Co, Alfredo, Philosophy of Ancient China (Manila: UST Printing Office, 1992).

Confucius, The Analects of Confucius (An Online Teaching Translation), trans. by Robert Eno, in Indiana University Bloomington (2015), $<$ http://www.indiana.edu/ p374/Analects of Con-fucius \%28Eno2015\%29.pdf $>, 18$ October 2016.

David Patterson, "The Philosophical Warrant for Genocide," in Genocide and Human Rights: A Philosophical Guide, ed., John K. Roth (New York: Palgrave Macmillan, 2005).

Gaita, Raimond, "Refocusing Genocide: A Philosophical Responsibility," in Genocide and Human Rights: A Philosophical Guide, ed., John K. Roth (New York: Palgrave Macmillan, 2005).

Garcia, Elenita, dlR., "What's the Matter with Philosophy? Reflections on Philosophy and its Role in Genocides," Professorial Chair lecture presented at the Dr. Emerita S. Quito Professorial Lecture in the History of Thought, De La Salle University.

Gottlieb, Roger, "The Human Material is Too Weak," in Genocide and Human Rights: A Philosophical Guide, ed., John K. Roth (New York: Palgrave Macmillan, 2005).

${ }^{62}$ John K. Roth, “After? ... Meaning What?" in Genocide and Human Rights, 327.

(c) 2017 Elenita dIR. Garcia

http://www.kritike.org/journal/issue 20/garcia june2017.pdf

ISSN 1908-7330

(cc) BY-NC-ND 


\section{GENOCIDE AND PHILOSOPHY}

Grob, Leonard, "Genocide and the Totalizing Philosopher: A Levinasian Analysis," in Genocide and Human Rights: A Philosophical Guide, ed., John K. Roth (New York: Palgrave Macmillan, 2005).

Hegel, Georg Wilhelm Friedrich, The Philosophy of History, trans. J. Sibree, (Ontario: Batoche Books, 2001).

Hume, David, "Of National Characters," in Essays, Moral, Political, and Literary, in Library Economics Liberty, <http://www.econlib.org/library/LFBooks/Hume/hmMPL-21.html\#PartI>, 5 March 2017.

John K. Roth, "After? ... Meaning What?" in Genocide and Human Rights: A Philosophical Guide, ed., John K. Roth (New York: Palgrave Macmillan, 2005).

"Prologue: Philosophy and genocide," in Genocide and Human Rights: A Philosophical Guide, ed., John K. Roth (New York: Palgrave Macmillan, 2005).

Kant, Immanuel, Observations on the Feelings of the Beautiful and the Sublime, trans. by John T. Goldthwait (Berkeley, Los Angeles, CA: University of California Press, 2003).

Lao Zi, Tao Te Ching, trans. by S. Mitchell, in Internet East Asian History Sourcebook (20 July 1995), <http://acc6.its.brooklyn.cuny.edu/ phalsall/texts/taote-v3.html\#7>, 18 October 2016.

Levinas, Emmanuel, Otherwise than Being, or, Beyond Essence, trans. A. Lingis (The Hague: Nijhoff, 1981).

Locke, John, An Essay Concerning Human Understanding, in Some Texts from Early Modern Philosophy (2012), $<$ http://www.earlymoderntexts.com Lassets/pdfs/locke1690book1.pdf>, 7 March 2017.

The Fundamental Constitutions of Carolina: March 1, 1669, in The Avalon Project: Documents in Law, History, and Diplomacy, $<$ http://avalon.law.yale.edu/17th cen-tury/nc05.asp>, 7 March 2017.

Lumsden, Simon, "Absolute Difference and Social Ontology: Levinas Face to Face with Buber and Fichte," in Human Studies, 23 (2000).

Mark, Michael, "The Rational Constitution of Evil: Reflections on Franz Baermann Steriner's Critique of Philosophy," in Genocide and Human Rights: A Philosophical Guide, ed., John K. Roth (New York: Palgrave Macmillan, 2005).

Matsuura, Koïchiro, “Message from Mr. Koïchiro Matsuura, Director-General of UNESCO on the occasion of the International Day of Commemoration in Memory of the Victims of the Holocaust," in UNESCO (27 January 2009), <http://unesdoc.unesco.org/images/0017/001794/179409e.pdf $>, 15$ October 2016.

"Message from Mr. Koichiro Matsuura, Director-General of UNESCO, on the occasion of World Philosophy Day," in UNESCO

(20 November 2008), <http://en.unesco.kz/message-from-mr- 
koichiro-matsuura-director-general-of-unesco-on-the-occasion-ofworld-2008-11-18>, 15 October 2016.

Michael Morgan, "Shame, the Holocaust, and the Dark Times," in Genocide and Human Rights: A Philosophical Guide, ed., John K. Roth (New York: Palgrave Macmillan, 2005).

Moore, Charles A., "Introduction: The Humanistic Chinese Mind," in The Chinese Mind: Essentials of Chinese Philosophy and Culture, ed. by Charles A. Moore (Honolulu: East-West Center Press, 1967).

Nietzsche, Friedrich, The Gay Science, trans. by Walter Kaufmann (New York: Random House, 1974).

Norman Geras, "Genocide and Crimes against Humanity," in Genocide and Human Rights: A Philosophical Guide, ed., John K. Roth (New York: Palgrave Macmillan, 2005).

Plato, The Republic, trans. by C.D.C Reeve (Indianapolis, Cambridge: Hackett Publishing Company, Inc., 2004).

Radhakrishnan, Sarvepalli and Charles A. Moore, eds., A Sourcebook in Indian Philosophy (Princeton, NJ: Princeton University Press, 1957).

Radhakrishnan, Sarvepalli, Eastern Religions and Western Thought (New York: Oxford University Press, 1959).

Raju, P.T., "Religion and Spiritual Values in Indian Thought," in The Indian Mind, ed. by Charles A. Moore (Honolulu: East-West Center Press, 1967).

Raveh, Inbar and Rotem Wagner, I Never Even Lived: A Teaching Unit - Women in Holocaust Literature (Jerusalem: Yad Vashem, 2000).

Richard Rorty, Contingency, Irony and Solidarity (New York: Cambridge University Press, 1989), xiv.

Roth, John K. "Genocide and the 'Logic' of Racism," in Genocide and Human Rights: A Philosophical Guide, ed., John K. Roth (New York: Palgrave Macmillan, 2005).

Saksena, S.K., "Relation of Philosophical Theories to the Practical Affairs of Men," in The Indian Mind, ed. by Charles A. Moore (Honolulu: EastWest Center Press, 1967).

Samtani, Narayan Hemandas, trans., Gathering the Meanings: The Compendium of Categories: The Arthavinishcaya Sutra and Its Commentary Nibhandana (California: Dharma Publishing, 2002).

Santilli, Paul, "Philosophy's Obligation to the Human Being in the Aftermath of Genocide," in Genocide and Human Rights: A Philosophical Guide, ed., John K. Roth (New York: Palgrave Macmillan, 2005).

Simon, Thomas W., "Genocide, Evil, and Injustice: Competing Hells," in Genocide and Human Rights: A Philosophical Guide, ed., John K. Roth (New York: Palgrave Macmillan, 2005).

(c) 2017 Elenita dIR. Garcia http://www.kritike.org/journal/issue 20/garcia june2017.pdf ISSN 1908-7330 


\section{GENOCIDE AND PHILOSOPHY}

Sontag, Frederick, "How Should Genocide Affect Philosophy?" in Genocide and Human Rights: A Philosophical Guide, ed., John K. Roth (New York: Palgrave Macmillan, 2005).

Tatz, Colin, "The Doctorhood of Genocide," in Genocide and Human Rights: A Philosophical Guide, ed., John K. Roth (New York: Palgrave Macmillan, 2005).

"Uddalaka and Svetaketu - story from the Brihadaranyaka Upanishad," in Hindu Swayamsevak Sangh's Balagokulam: Hindu Dharma for Kid, Teachers, $\mathcal{E}$ Parents, <http://www.balagokulam.org/kids/stories Luddalaka.php>, 18 October 2016.

United Nations, "Convention on the Prevention and Punishment of the Crime of Genocide," in United Nations Human Rights - Office of the High Commissioner (9 December 1948), <http://www.ohchr.org/EN/ProfessionalInterest/Pages/CrimeOfGenocide.aspx $>, 15$ October 2016.

Voltaire, "Septième Lettre d'Amabed," in Les Lettres d'Amabed, vol. 21 of Oeuvres Complete de Voltaire (Paris: Garnier, 1877). [Voltaire, "Seventh Letter of Amabed," in The Letters of Amabed, vol. 21 of Complete Works of Voltaire (Paris: Garnier, 1877).]

Ward, Julie, K. "The Roots of Modern Racism: Early Modern Philosophers on Race," in The Critique, (September/October 2016), <http://www.thecritique.com/articles/the-roots-of-modern-racism/>, 7 March 2017. 